\title{
Retracted: Why Fish Oil Fails: A Comprehensive 21st Century Lipids-Based Physiologic Analysis
}

\author{
Journal of Lipids \\ Received 4 November 2014; Accepted 4 November 2014; Published 5 November 2014 \\ Copyright (C) 2014 Journal of Lipids. This is an open access article distributed under the Creative Commons Attribution License, \\ which permits unrestricted use, distribution, and reproduction in any medium, provided the original work is properly cited.
}

The article titled "Why Fish Oil Fails: A Comprehensive 21st Century Lipids-Based Physiologic Analysis" [1], published in Journal of Lipids has been retracted as a result of an undeclared competing interest on the part of the manuscript's author.

\section{References}

[1] B. S. Peskin, "Why fish oil fails: a comprehensive 21st century lipids-based physiologic analysis," Journal of Lipids, vol. 2014, Article ID 495761, 15 pages, 2014. 